\title{
Does the Depreciation of RMB Exchange Rate Inhibit the Innovation of Export Enterprises?
}

\author{
Guohui Yang \\ School of Management, Jinan University, Guangzhou, China \\ Email:13535028757@139.com
}

How to cite this paper: Yang, G.H. (2018) Does the Depreciation of RMB Exchange Rate Inhibit the Innovation of Export Enterprises? Modern Economy, 9, 339-361. https://doi.org/10.4236/me.2018.92022

Received: January 16, 2018

Accepted: February 25, 2018

Published: February 28, 2018

Copyright (C) 2018 by author and Scientific Research Publishing Inc. This work is licensed under the Creative Commons Attribution International License (CC BY 4.0).

http://creativecommons.org/licenses/by/4.0/

\begin{abstract}
Based on the sample of Chinese A-share listed companies from 2011-2016, this paper examines the impact of RMB exchange rate depreciation on enterprise innovation from the perspective of investment motivation. The study found that the devaluation of the RMB exchange rate significantly inhibited the innovation of export enterprises. In the sample of export enterprises, this paper uses OLS regression to find that RMB devaluation significantly inhibits the innovation of export enterprises. Further study on the exporting enterprises group found that this conclusion is only significant in the sub-sample of private enterprises, small scale enterprises and enterprises with high industry competition degree. Because these enterprises have a stronger motivation to pursue profits, in case that the depreciation of RMB exchange rate is conducive to exports, they are more likely to increase their investment in production in order to expand their exports, ignoring innovation investment. This shows that the export enterprises are in the face of the short-term profit-making opportunities arising from the devaluation of the RMB, and the weakening of motivation for investment innovation is the mechanism of devaluation of the RMB to curb enterprise innovation. Finally, in the robustness test, this paper considers the lagging effect of RMB depreciation, and replaces the innovation index of enterprises, and the results are still consistent with the main regression results.
\end{abstract}

\section{Keywords}

RMB Exchange Rate, Enterprise Innovation, Investment Motivation, Capital Chasing Interest

\section{Introduction}

As an important price factor in opening up the macro-economy, the exchange rate plays an important role in the transformation of economic growth mode. It 
has a great impact on the import and export of enterprises and affects the production and operation of enterprises. Since 2005, the RMB has continued to appreciate. Until 2014, the RMB exchange rate devalued for the first time. On August 11, 2015, the People's Bank of China announced the adjustment of the central parity quotation system for the exchange rate of RMB against the U.S. dollar. As a result of this policy, the exchange rate of RMB further depreciated sharply. After entering 2016, the RMB continued to weaken. In the first half of 2016, the devaluation rate reached $5.84 \%$.

Innovation is the fundamental factor that determines economic development. In the future, the transformation of China's economic growth mode needs to attach importance to the innovation investment of enterprises. If the Chinese economy lacks innovative elements and efficiency, the rapid economic growth will not be able to sustain. Based on this, this article attempts to analyze the relationship between exchange rate changes and business innovation.

The contribution of this article mainly has the following two points. First, although a large number of documents have confirmed the aid effect of the devaluation of RMB on the export of products, they have neglected the negative effects it may have. This paper studies the microeconomic impact of depreciation of the RMB in recent years and finds that devaluation of the RMB inhibits exports enterprise innovation. Second, this also reveals the important role of exchange rate in the transformation of China's economic growth-driven mode from the micro-level and can provide important reference information for China to formulate its exchange rate policy and promote economic restructuring, which is of great practical significance.

The innovation of this article is as follows. The existing literature has mainly studied the relationship between exchange rate appreciation and enterprise innovation, and there is almost no literature on the relationship between devaluation and innovation. However, the impact mechanism of exchange rate appreciation and devaluation on enterprise innovation may be different. This paper finds that the depreciation of RMB exchange rate may affect the innovation of enterprises by affecting the investment motivation of the enterprises, and concludes that the transformation of investment motivation in the case of RMB depreciation is a new viewpoint that the exchange rate changes affect the innovation mechanism of enterprises.

\section{Literature Review}

\subsection{Influence Factors of Enterprise Innovation}

The innovation activities of enterprises are influenced by many factors of its internal and external factors. There are many literatures that affect the innovation of enterprises, which are mainly divided into three parts. The first part is a paper that examines company-level characteristics and innovation activities. The literature mainly includes how the corporate governance and venture capital and other internal characteristics influence enterprise innovation process, characte- 
ristics and achievements. The second part is the study of the relationship between the economic characteristics of the whole market (such as product market competition, import penetration, banking competition, etc.) and enterprises' investment in innovation. The third part is the analysis of how the macro-level social or national characteristics (such as national institutional characteristics, laws and policies, the development of financial markets, etc.) affect the business innovation.

\subsubsection{Company Level Characteristics and Innovative Literature}

From the perspective of corporate governance, the influencing factors of firm innovation are analyzed. Pan Hongbo and Chen Shilai (2017) took the 2004-2012 A-share family-owned listed companies as a sample and found that the kinship of CEO or chairman can significantly improve the innovation level of family-owned firms [1]. Based on the data of A-share listed companies from 2001 to 2013, Song Jianbo and Wen Wen (2016) found that the overseas background of directors has a positive role in promoting enterprise innovation [2]. Chen Chuang and Liu Tianyu (2012) found that the founding managers can curb their $\mathrm{R} \& \mathrm{D}$ investment using data from listed companies on small and medium-sized board in the Shenzhen Stock Exchange [3].

In terms of financing constraints and corporate innovation literature, Liu Shengqiang et al. (2015) took the annual report data of Chinese listed companies from 2009 to 2012 as a sample and found that there was a significant negative correlation between financing constraints and R \& D investment [4]. Agency costs were significantly and positively correlated with $\mathrm{R} \& \mathrm{D}$ investment. Miwako and Allan (2013) found that the higher the level of regional financial development, the lower the financial constraints on the R \& D investment activities of enterprises [5].

Pan Yue et al. (2015) studied the relationship between litigation and corporate innovation in Chinese listed companies and found that financial litigation had a significant negative inhibitory effect on corporate innovation activities, while product litigation had a significant positive impact on corporate innovation activities [6]. Yang Daoguang et al. (2017) took the listed companies of China's A-shares in 2007-2009 as a sample and found that both the number of non-negative reports and the total number of reports were significantly and positively related to the level of enterprise innovation [7]. Bernstein (2015) found that after the IPO, the quality of internal innovation declined, accompanied by the departure of skilled workers and the reduction of remaining skilled workers, but the listed companies gained new human capital and external innovation [8]. Manso (2011) points out that maximizing tolerance for early failures and rewards on the success of long-term innovation is conducive to stimulating innovation, and long-term compensation programs, job stability, and timely feedback can potentially stimulate innovation [9].

\subsubsection{Industrial Characteristics and Innovation Literature}

Li Jian et al. (2016) took the listed companies from 2007 to 2012 as samples and 
found that there exists an inverted U-shaped relationship between product market competition and technological innovation faced by manufacturing enterprises [10]. Using a database of China's industrial enterprises from 1998 to 2007 by the National Bureau of Statistics, Jian Ze et al. (2017) found that market competition promoted the increase of $\mathrm{R} \& \mathrm{D}$ investment at the enterprise level, promoted product innovation and process innovation, and promoted real profit growth through technological progress [11]. Zhang Jie et al. (2014) used Chinese industrial enterprises database from 1998 to 2007, and empirical studies found that there was a significant and steady positive relationship between competition and innovation in the Chinese context [12]. Dai Kuizao and Liu Youjin (2013) selected panel data of the sub-industries in China's high-tech industry from 1995 to 2010 and found that the increase in marketization has had a positive impact on the innovation performance of China's high-tech industries [13].

\subsubsection{Macro-Level Factors and Innovative Literature}

1) Related documents of national policy and enterprise innovation

Li Wenjing and Zheng Manni (2016) found that there was a significant increase in patent applications of companies inspired by industrial policies in 2001-2010, but only a significant increase in non-invention patents, implying that these companies pursue "quantity" while ignoring "quality" [14]. Qin Xuezheng et al. (2012) used data from the survey of SMEs in the earthquake-stricken area of Deyang in Sichuan in 2009 and found that Technology Planning policy significantly increased the probability of product innovation and method innovation, and this policy was more significant for companies with high R \& D input densities [15]

2) Related documents of industrial development and enterprise innovation

Wang Wenchun and Rong Zhao (2014) used the data of industrial enterprises above designated size in 35 large and medium-sized cities in China from 1999 to 2007 and found that the faster the rise of house prices, the weaker the innovation tendency of local enterprises [16]. Wang Hongjian et al. (2016) selected all listed A-share companies in 2009-2014 as the original sample, pointing out that the cross-industry arbitrage significantly reduces the innovation activities of the real enterprises and shows the creative restraint effect [17].

3) Law and Business Innovation Related Literature

Gao Jie et al. (2015) made use of 2004-2009 listed companies in small and medium-sized board to find that intellectual property protection and market organization service conditions have significantly promoted enterprise innovation [18]. Ni Xiao Ran and Zhu Yujie (2016) built a double-difference model based on the implementation of the 2008 Labor Contract Law and found that the implementation of the Labor Contract Law significantly enhanced the R \& D investment of labor-intensive enterprises [19]. Wang Haicheng, Lu Tie (2016) Based on a quasi-natural experiment of "three trials and one unification" of criminal, civil and administrative cases involving intellectual property that started in 2006 in Guangdong Province, found that the improvement of the 
judicial protection of intellectual property rights can significantly promote the innovation of enterprises [20].

\subsection{Economic Consequences of Exchange Rate Changes}

$\mathrm{Xu}$ Jiayun et al. (2015) analyzed the impact of RMB exchange rate changes on the export of multi-product enterprises using a matching database of China's industrial enterprises and found that an appreciation of real RMB exchange rate can effectively enhance the export extension period of core products of enterprises so that enterprises can pay more attention to core product production, which is a channel to enhance the competitiveness of export products [21]. Harris (2001) used Canada's sample to analyze the link between exchange rate changes and productivity, and found that the real exchange rate has short-term and long-term impacts on productivity [22]. Zhang Huiqing and Tang Haiyan (2012) respectively found that the appreciation of RMB exchange rate will have a significant negative impact on exports based on the time series and firm-level data [23]. Li Hongbin et al. (2011) used panel data of Chinese importers and exporters from 2000 to 2006 and found that the appreciation of RMB effective exchange rate would have a negative impact on China's export and import enterprises [24]. Liang Zhonghua et al. (2014) and Wu Guoding (2017) through empirical research found that RMB appreciation has had a negative impact on the profitability of exporters [25] [26]. Based on the micro-data of industrial enterprises and the highly detailed customs data from 2000 to 2007, Tong Jiadong et al. (2016) found that the appreciation of real effective exchange rate of RMB has a significant inhibitory effect on export decisions, export volume, export prices and export volume of Chinese industrial enterprises [27]. Li H et al. (2015) Empirical study finds that RMB appreciation reduces exporters' export volume and export possibilities [28].

Mao Risheng et al. (2017) used the data of Chinese industrial enterprises from 1998 to 2009 and the data of customs sub-product levels and found that the devaluation of RMB exchange rate relative to appreciation has a more significant impact on export change and conversion, and the evaluation will have the same direction significant impact on export expansion and contraction rate [29]. According to Campa and Goldberg (1995), changes in exchange rates have an impact on corporate capital equipment investment by affecting corporate profits and the impact of exchange rate on corporate investment varies with the degree of export orientation of the enterprise [30].

\subsection{Exchange Rate Changes and Corporate Innovation Literature}

However, there is some but not much literature on the current research on exchange rate changes and corporate innovation. Liu Qiren and Huang Jianzhong (2017) used the matching database of "Customs" and "National Tax Survey" from 2008 to 2011 and found that the appreciation of the effective exchange rate and the increase of the expected volatility were both significantly detrimental to 
R \& D investment of export enterprises [31]; Yu Jingwen (2016) used data from the enterprise level in China's industrial enterprises database from 1998 to 2007 to find that the intensified market competition caused by the appreciation of the RMB promoted the innovation of enterprises, and found that the appreciation of the RMB strengthened the incentives for innovation and increased the output value of new products accounting for the proportion of total industrial output value [32]; Ekholm et al. (2012) used data from Norwegian manufacturing firms to examine the impact of exchange rate appreciation on firm performance and found that increased competition due to exchange rate appreciation increased the productivity and innovation of exporters [33]. Tang (2010) built a theoretical model of exchange shocks and R \& D innovation using data from Canada and found that competitive pressures from the appreciation of the currency led firms to adopt new technologies to increase productivity [34].

\subsection{The Limitations of History Literature}

The existing literature has focused mainly on the study of relationship between exchange rate changes and productivity and corporate investment, and only a few articles directly study the relationship between exchange rate changes and innovation. However, these articles still have the following limitations: First, they mainly focus on the relationship between the appreciation of the exchange rate and the innovation of enterprises. They do not study the relationship between exchange rate and innovation in the context of sustained currency devaluation. Second, they did not study the specific mechanism of exchange rate changes and enterprise innovation in depth. However, this study finds that RMB devaluation affects the innovation of export enterprises through "shifting the investment direction of enterprises". The research in this article will make up for these limitations.

\section{Theoretical Analysis and Hypothesis}

According to the law of capital fame and fortune, when enterprises are facing good investment opportunities, they should choose to expand the scale of investment to seize good investment opportunities to create corporate value. When faced with poor investment opportunities, they should choose to reduce the investment scale in order to reduce loss of investment. In the enterprise investment projects, there are two types of investment choices: innovative investments with long-term effects and high risks, and short-term quick-impact and low-risk capital investments. When faced with investment choices, enterprises will make a trade-off between short-term capital investment and long-term innovation investment. When the rate of return on capital investment is higher, the enterprise will choose to increase the scale of capital investment and reduce the capital available for investment in innovation; on the contrary, enterprises will reduce the scale of capital investment, which has more capital to make innovative investments. 
In the scenario of exchange rate changes, the appreciation of RMB exchange rate will increase the difficulty of export enterprises to export and reduce the profitability of export enterprises. Li Hongbin et al. (2011) found that the appreciation of $\mathrm{RMB}$ effective exchange rate would have a negative impact on China's export and import enterprises [28]; Liang Zhonghua et al. (2014) and Wu Guoding (2017) pointed out that a RMB appreciation has a negative impact on the profitability of exporters [29] [30]. In addition, Wu Guoding et al. (2015) found that RMB appreciation has a negative impact on the investment of enterprises through export revenue channels, and this negative impact increases as the export dependence of enterprises increases [35]. Therefore, under the circumstance of appreciation of RMB, enterprises are more likely to abandon export-oriented investment which is more difficult to gain profits. In order to survive and develop, this will lead to more motivation for $\mathrm{R} \& \mathrm{D}$ investment and ultimately promote the innovation of enterprises. Contrary to the impact of the appreciation of the $\mathrm{RMB}$ exchange rate, devaluation of the RMB exchange rate has raised the competitive conditions for the export products of enterprises and greatly increased the returns from the productive inputs of enterprises. For example, Mao Risheng et al. (2017) found that the depreciation of the RMB exchange rate relative to the appreciation has more significant impact on export changes and conversion, and the devaluation will have a significant export expansion and contraction rate in the same direction [33]. Therefore, under the circumstance of devaluation of the $\mathrm{RMB}$, enterprises are more likely to choose export investment with short-term profit opportunities and low risk, which will lead to a weaker motivation for their investment $\mathrm{R} \& \mathrm{D}$ and eventually inhibit the innovation of enterprises. Therefore, this article proposes Hypothesis 1:

$\mathrm{H} 1$ : Under the same conditions, the depreciation of the RMB exchange rate hinders the innovation of export enterprises.

As for the depreciation of the RMB exchange rate, different types of enterprises or enterprises of the same type at different periods, the propensity to increase their export investment for short-term profits will be different, and the extent to which their innovative investment will be affected by export investment will be somewhat different, too. Based on the basic hypothesis, this paper further deduces the following hypothesis that can be tested.

For state-owned enterprises, private enterprises take less social functions such as national economic stability, local construction and employment. They pay more attention to the purpose of profit-making enterprises. Under the devaluation of $\mathrm{RMB}$ exchange rate, when $\mathrm{RMB}$ devaluation enhances the competitiveness of export products, private enterprises are more likely to increase their earnings by short-term expansion of exports rather than dedicated to high-risk and long-term R \& D investment. Under such circumstances, it is very easy for enterprises to withdraw funds from $\mathrm{R} \& \mathrm{D}$ and invest in export business. Private enterprises to increase investment in production to increase exports, squeeze out $\mathrm{R} \& \mathrm{D}$ investment in these enterprises, resulting in "squeeze R \& D effect" and 
ultimately reduce business innovation. Based on the above considerations, this paper proposes Hypothesis 2:

$\mathrm{H} 2$ : Under the same conditions, devaluation of the RMB exchange rate will further curb the innovation of private exporters.

Compared to large-scale enterprises, small-scale enterprises have less capital accumulation and limited ability to take risks, and the living environment they face is even worse. In order to survive and develop, small-scale enterprises are more inclined to invest in short-term profit-making projects. In the case of devaluation of the RMB, when the devaluation of the RMB improves the competitiveness of export products, small-scale enterprises are more likely to increase their returns by short-term expansion of exports rather than investing in high-risk and long-term R \& D investments. Under such circumstances, it is very easy for enterprises to withdraw funds from $\mathrm{R} \& \mathrm{D}$ and invest in export business. Small-scale enterprises to increase investment in production to increase exports, squeeze out R \& D investment in these enterprises, resulting in "squeeze R \& D effect" and ultimately reduce business innovation. Based on the above considerations, this paper proposes Hypothesis 3:

$\mathrm{H} 3$ : Under the same conditions, the devaluation of RMB exchange rate will further curb the innovation of small-scale export enterprises.

According to the innovative theory proposed by Schumpeter (1942), firms that experience lower market competition are more likely to earn excess profits and are able to afford higher innovation risks, thus benefiting from innovation. Therefore, the less competitive firms have the motivation to innovate Strong [36]. Compared with enterprises with low industry competition, enterprises with high industry competition face fiercer market competition and less profits, which makes their business performance more urgent. Under the devaluation of the RMB, which can enhances the competitiveness of export products, enterprises with high industry competition are more likely to increase their profits by short-term export expansion instead of focusing on high-risk and long-term R \& $\mathrm{D}$ investment. Under such circumstances, it is very easy for enterprises to withdraw funds from research and development and invest in export business. Enterprises with a high level of competition in the industry will increase their investment in production to increase their exports, resulting in a "squeeze-out of R \& D effect", squeezing R \& D investment from these enterprises and eventually reducing their innovation. Based on the above considerations, this paper proposes Hypothesis 4:

H4: Under other conditions, the depreciation of RMB exchange rate will further inhibit the innovation of export enterprises with high degree of competition in the industry.

For the above four assumptions, based on the sample of Chinese A-share listed companies from 2011-2016, this paper uses OLS regression to verify the relation between RMB devaluation and the innovation of export enterprises. Further study on the exporting enterprises group of the sub-sample of private 
enterprises, small scale enterprises and enterprises with high industry competition degree, we use the method of grouping for comparative verification.

\section{Research Design and Empirical Test}

\subsection{Sample Selection}

The research object of this paper is Chinese A-share listed company from 2011 to 2016. The reason to start from 2011 is that although the CSRC requires public companies to disclose their R \& D investment information since 2007, the amount of company data disclosed before 2011 is small and of poor quality and therefore not included in the regression sample of this article. Financial data is from the Cathay Pacific's CSMAR database and WIND database, and the software used in the study is STATA. The sample was screened according to the following principles: 1) excluding the listed companies whose trading status was ST and PT; 2) excluding financial listed companies; 3) excluding the samples that were not exported during the sample period; 4) excluding the missing financial data. A total of 8536 companies' annual observations were obtained after the samples were processed. Meanwhile, winsorize processing was performed on all the continuous variables at the upper and lower $1 \%$ level to avoid the influence of outliers.

\subsection{Variable Definitions}

\subsubsection{Business Innovation}

$\mathrm{Rd}$, Rda is the explanatory variable, which represents the enterprise innovation activity. At present, there are two ways to measure the enterprise innovation in the literature: innovation investment and innovation output (i.e. the number of patents). These two indicators have their own advantages and disadvantages, of which innovation investment is relatively true and reliable, but cannot effectively measure the efficiency of enterprise innovation. Although patent data can better reflect the true level of innovation in enterprises, there is a problem of inconsistent statistical standards (for example, how to calculate Subsidiary patents, etc.), so using the number of patents to represent the quality of enterprise innovation is difficult to guarantee. Because the cost of R \& D investment is more affected by the company's accounting policies, so it does not really represent the actual business innovation ability. Taking into account the above factors and considering the practice of Dang Li et al. (2015), Liu Qiren et al. (2017) and Yu Yongze et al. (2017), we use capitalized R \& D investment to represent enterprise innovation in the main test of this article [4] [37] [38].

\subsubsection{RMB Exchange Rate}

Rate is an explanatory variable, indicating the nominal exchange rate of RMB against the U.S. dollar. First of all, among the exporting enterprises, most enterprises adopt the US dollar in quotation although the target market is more. The exchange rate of RMB to the US dollar has a special position in the export trade of enterprises. Second, there has been much controversy in the literature on 
whether nominal or real exchange rates should be used. However, Alvarez et al. (2009) pointed out that the two are actually very close [39]. First, the gap between the real exchange rate and the nominal exchange rate is getting smaller as the exchange rate can float (Clark et al., 2004) [40]. In addition, the empirical results using the real exchange rate and the nominal exchange rate are very close (McKenzie, 1999) [41]. Finally, enterprises and managers often use the nominal exchange rate as an indicator to judge whether the exchange rate is favorable. The logic of this article is that the devaluation of the RMB causes the enterprise's short-sighted investment behavior (that is, the resource allocation is shifted to the production investment to expand exports) and ignoring the long-term, risky innovation investment. Therefore, it may be more appropriate to adopt the nominal exchange rate in this article. At the same time, referring to the relevant literature (Tan Xiaofen et al., 2016; Lu Zhiwang, 2015), the paper uses the nominal exchange rate of RMB to the US dollar to indicate the exchange rate changes [42] [43].

\subsubsection{Control Variables}

With reference to the existing literature (Wang Hongjian et al., 2016; Yu Jingwen, 2016; Cai Xiaohui and Ru Yucong, 2016; Luo Changyuan and Ji Xinyu, 2015; Zhang Jie et al., 2011) [5] [18] [23] [44] [45], this paper controls the size, Lev, Soe, Roe, cash of operating cash, product market competition (HHI), cash flow, Financing constraints $(\mathrm{Fc})$, the number of employees (Employee) and other indicators when examining the impact of RMB devaluation on business innovation. At the same time, the article also controls the fixed effects of the industry and the province. The main variables are defined in Table 1.

\subsection{Descriptive Statistics}

Table 2 reports the descriptive statistics of the major variables. Among them, the $\mathrm{R} \& \mathrm{D}$ input (Rd) $1 / 4$ quantiles and the median is 0 , indicating that the number of enterprises with $\mathrm{R} \& \mathrm{D}$ investment is small; the standard deviation is 7.171, which indicates that there is a big individual difference in $\mathrm{R} \& \mathrm{D}$ investment and innovation investment and the difference is big; the analysis of Rda for asset standardization is consistent with $\mathrm{Rd}$. The average nominal exchange rate of $\mathrm{RMB}$ is 6.340 , the minimum is 6.143 and the maximum is 6.640 , which shows that the exchange rate changes obviously in the sample interval. The remaining indicators compared with the existing literature did not exist significant differences and are within a reasonable range, thus ensuring the stability of the regression results.

\subsection{Empirical Test}

In order to investigate the impact of RMB exchange rate on the innovation of enterprises, this paper refers to the existing literature (Yu Yongze and Zhang Shaohui, 2017; Wang Hongjian et al., 2016; Yu Jingwen, 2016; Tan Xiaofen et al., 2016; Dang Li et al., 2015) [5] [23] [38] [39] [42] and set the regression model to 
Table 1. Definitions of the main variables.

\begin{tabular}{|c|c|c|c|}
\hline & variable name & $\begin{array}{l}\text { Variable } \\
\text { code }\end{array}$ & Variable definitions \\
\hline \multirow{2}{*}{$\begin{array}{l}\text { Explained } \\
\text { variable }\end{array}$} & $\mathrm{R} \& \mathrm{D}$ index 1 & $\mathrm{Rd}$ & $\begin{array}{l}\text { Ln (capitalization of } \mathrm{R} \& \mathrm{D} \text { investment of } \\
\text { enterprises that year }+1 \text { ) }\end{array}$ \\
\hline & $\mathrm{R} \& \mathrm{D}$ index 2 & Rda & $\begin{array}{l}\text { Capitalization of R \& D investment of } \\
\text { enterprises that year/total assets } * 100\end{array}$ \\
\hline \multirow[t]{4}{*}{$\begin{array}{l}\text { Explanatory } \\
\text { variables }\end{array}$} & $\begin{array}{l}\text { RMB exchange } \\
\text { rate }\end{array}$ & Rate & $\begin{array}{l}\text { Annual nominal exchange rate of RMB } \\
\text { against US dollar under the direct quotation } \\
\text { method (monthly average) }\end{array}$ \\
\hline & $\begin{array}{l}\text { Whether the } \\
\text { company is an } \\
\text { exporter }\end{array}$ & Treat & $\begin{array}{l}\text { The company belongs to the export } \\
\text { enterprise (experimental group) is defined } \\
\text { as 1, belongs to non-exporting enterprises } \\
\text { (control group) is defined as } 0\end{array}$ \\
\hline & $\begin{array}{l}\text { “ } 8.11 \text { ” exchange } \\
\text { reform event }\end{array}$ & Pose & $\begin{array}{c}\text { Defined as } 1 \text { if " } 8.11 \text { " exchange reform event } \\
\text { occurred in the year of } 2015 \text { and } 2016 \text { and } \\
\text { beyond (2015-2016) and otherwise } 0 \\
(2011-2014)\end{array}$ \\
\hline & $\begin{array}{l}\text { If " } 8.11 \text { " and if } \\
\text { exporter's pay by }\end{array}$ & $\begin{array}{l}\text { Treat } \\
\text { Pose }\end{array}$ & Treat ${ }^{\star}$ Pose \\
\hline \multirow[t]{11}{*}{$\begin{array}{l}\text { Control } \\
\text { variables }\end{array}$} & Company Size & Size & $\begin{array}{l}\text { Natural logarithm of firm's total asset } \\
\text { size }=\text { Ln (total asset value }+1)\end{array}$ \\
\hline & Financial leverage & Lev & $\begin{array}{c}\text { Enterprise debt ratio }=\text { total liabilities } / \text { total } \\
\text { assets }\end{array}$ \\
\hline & Business age & Age & $\begin{array}{c}\text { Business Age }=\text { Year of the Year }- \text { Year of } \\
\text { Establishment }\end{array}$ \\
\hline & Nature of property & Soe & $\begin{array}{l}\text { The actual controller of the enterprise is the } \\
\text { central government or local government, the } \\
\text { value is } 1 \text {, otherwise } 0\end{array}$ \\
\hline & Profitability & Roe & $\begin{array}{l}\text { Enterprise total return on assets }=\text { current } \\
\text { net profit/end of the net assets }\end{array}$ \\
\hline & $\begin{array}{l}\text { Net cash flow from } \\
\text { operating activities }\end{array}$ & Cfo & $\begin{array}{c}\text { Net cash flow generated from operating } \\
\text { activities = net cash flow from operating } \\
\text { activities/total assets at the end of the period }\end{array}$ \\
\hline & $\begin{array}{l}\text { Product market } \\
\text { competition }\end{array}$ & Hhi & $\begin{array}{l}\text { Using Company Revenue to Calculate } \\
\text { Industry Annual Herfindahl Index (HHI) }\end{array}$ \\
\hline & $\begin{array}{l}\text { Financing } \\
\text { constraints }\end{array}$ & $\mathrm{Fc}$ & $\begin{array}{c}\text { Financing constraints }=\text { (operating } \\
\text { assets }- \text { operating liabilities)/total assets at } \\
\text { the end of the period }\end{array}$ \\
\hline & $\begin{array}{l}\text { Number of } \\
\text { employees }\end{array}$ & Employee & $\begin{array}{l}\text { Number of employees }=\mathrm{Ln}(\text { number of } \\
\text { employees in the enterprise at the year }+1)\end{array}$ \\
\hline & $\begin{array}{l}\text { Ownership } \\
\text { concentration }\end{array}$ & shrcr1 & $\begin{array}{l}\text { The largest shareholder of the } \\
\text { company shareholding ratio }\end{array}$ \\
\hline & Export earnings & Export & $\begin{array}{l}\text { Export income }=\text { Ln }(\text { enterprise export } \\
\text { income of the year }+1)\end{array}$ \\
\hline
\end{tabular}


Table 2. Descriptive statistics of major variables.

\begin{tabular}{ccccccccc}
\hline $\begin{array}{c}\text { Variable } \\
\text { Name }\end{array}$ & Observed & Mean & $\begin{array}{c}\text { Standard } \\
\text { Deviation }\end{array}$ & P25 & Median & P75 & Minimum Maximum \\
\hline Rd & 8535 & 4.544 & 7.572 & 0 & 0 & 14.12 & 0 & 19.74 \\
Rda & 8536 & 0.370 & 0.931 & 0 & 0 & 0.0253 & 0 & 5.132 \\
Treat & 8536 & 1 & 0 & 1 & 1 & 1 & 1 & 1 \\
Pose & 8536 & 0.391 & 0.488 & 0 & 0 & 1 & 0 & 1 \\
Treat Pose & 8536 & 0.391 & 0.488 & 0 & 0 & 1 & 0 & 1 \\
Rate & 8536 & 6.340 & 0.181 & 6.196 & 6.227 & 6.461 & 6.143 & 6.640 \\
Size & 8536 & 21.96 & 1.241 & 21.07 & 21.77 & 22.59 & 19.24 & 25.85 \\
Age & 8536 & 16.01 & 4.955 & 13 & 16 & 19 & 6 & 31 \\
Lev & 8536 & 0.409 & 0.211 & 0.238 & 0.392 & 0.571 & 0.0436 & 0.950 \\
Roe & 8536 & 0.0652 & 0.100 & 0.0286 & 0.0664 & 0.109 & -0.473 & 0.380 \\
Soe & 8536 & 0.322 & 0.467 & 0 & 0 & 1 & 0 & 1 \\
Shrcrl & 8536 & 35.12 & 14.60 & 23.91 & 33.53 & 44.82 & 8.774 & 75.42 \\
Cfo & 8536 & 0.0414 & 0.0679 & 0.00480 & 0.0400 & 0.0820 & -0.200 & 0.249 \\
Employee & 8536 & 7.737 & 1.196 & 6.908 & 7.632 & 8.452 & 4.007 & 11.09 \\
Export & 8536 & 18.91 & 2.227 & 17.69 & 19.12 & 20.34 & 6.060 & 23.37 \\
Hhi & 8536 & 0.00530 & 0.0106 & 0.00110 & 0.00130 & 0.00560 & 0.000900 & 0.143 \\
\hline & & & & & & & &
\end{tabular}

be tested as follows:

$$
\mathrm{Rd}=\beta_{0}+\beta_{1} \text { rate }+\alpha X^{\prime}+\text { Industry }+ \text { Province }+\varepsilon
$$

For the formula (1), $\beta_{0}$ intercept, $\beta_{1}$ represents the coefficient of exchange rate changes on the impact of business innovation, $\alpha$ is the coefficient of the control, and $\varepsilon$ variable is the residual. Rd is the $\mathrm{R} \& \mathrm{D}$ investment index of an enterprise, which is equal to taking logarithm of "the enterprise's research and development investment in that year plus one". The larger the value, the more the R \& D investment and the more innovative ability. The Rate represents the $\mathrm{RMB}$ exchange rate. $\mathrm{X}$ represents the control variable, see Table 1 for the detailed definition. It should be noted that in the OLS empirical regression, the effect of exchange rate changes is absorbed if the OLS empirical regression controls the annual effect(in essence, the RMB exchange rate already contains the annual impact). Therefore, none of the OLS regression in this article controls the impact of the year.

As can be seen from Table 3, the RMB exchange rate has a negative correlation with $\mathrm{R} \& \mathrm{D}$ investment in the four columns of regression equations, both of which are significant. That is, the more depreciated the RMB, the more it inhibits the enterprises' innovation investment. Specifically, columns 1 and 3 only control industry and provincial effects. The results show that the coefficient of the RMB exchange rate is -0.7208 (columns 1) and -0.1333 (columns 3), and significantly negative at the level of $1 \%$. This means that RMB devaluation of 1 yuan each, the export business innovation level fell 72\%/13\%. Columns 2 and 4 
Table 3. RMB exchange rate fluctuation and enterprise innovation.

\begin{tabular}{|c|c|c|c|c|}
\hline & (1) & (2) & (3) & (4) \\
\hline & & & & \\
\hline \multirow[t]{2}{*}{ Rate } & $-0.7208^{\star * *}$ & $-1.1362^{\star * *}$ & $-0.1333^{\star * *}$ & $-0.1351^{* * *}$ \\
\hline & $(-2.65)$ & $(-3.94)$ & $(-4.18)$ & $(-4.02)$ \\
\hline \multirow[t]{2}{*}{ Size } & & $0.9289^{* * \star}$ & & $-0.0483^{\star}$ \\
\hline & & $(4.39)$ & & $(-1.86)$ \\
\hline \multirow[t]{2}{*}{ Age } & & 0.0023 & & -0.0022 \\
\hline & & $(0.08)$ & & $(-0.57)$ \\
\hline \multirow[t]{2}{*}{ Lev } & & $-3.0877^{\star * *}$ & & $-0.3243^{* * *}$ \\
\hline & & $(-2.70)$ & & $(-2.62)$ \\
\hline \multirow[t]{2}{*}{$\mathrm{Fc}$} & & -0.4013 & & -0.0123 \\
\hline & & $(-0.45)$ & & $(-0.12)$ \\
\hline \multirow[t]{2}{*}{ Roe } & & -1.3347 & & -0.0311 \\
\hline & & $(-1.25)$ & & $(-0.26)$ \\
\hline \multirow[t]{2}{*}{ Soe } & & 0.4377 & & 0.0675 \\
\hline & & $(1.08)$ & & $(1.28)$ \\
\hline \multirow[t]{2}{*}{ Shrcr1 } & & $-0.0465^{* * *}$ & & $-0.0043^{* * *}$ \\
\hline & & $(-4.27)$ & & $(-3.31)$ \\
\hline \multirow[t]{2}{*}{ Cfo } & & $-4.9572^{* * *}$ & & 0.0932 \\
\hline & & $(-3.19)$ & & $(0.43)$ \\
\hline \multirow[t]{2}{*}{ Employee } & & 0.2588 & & $0.0780^{* * *}$ \\
\hline & & $(1.24)$ & & $(3.03)$ \\
\hline \multirow[t]{2}{*}{ Export } & & -0.1149 & & 0.0009 \\
\hline & & $(-1.50)$ & & $(0.10)$ \\
\hline \multirow[t]{2}{*}{ Constant } & $7.7255^{* * *}$ & $-6.5627^{\star}$ & $1.0481^{* * *}$ & $1.7893^{* * *}$ \\
\hline & $(3.37)$ & $(-1.68)$ & $(4.18)$ & $(3.81)$ \\
\hline Industry & Yes & Yes & Yes & Yes \\
\hline Province & Yes & Yes & Yes & Yes \\
\hline Observations & 8,535 & 8,535 & 8,536 & 8,536 \\
\hline Adj. $R^{2}$ & 0.0909 & 0.116 & 0.0754 & 0.0840 \\
\hline
\end{tabular}

Note: The parentheses in the table are the $\mathrm{Z} / \mathrm{T}$ values corrected by the corporate dimension Cluster; ${ }^{* * *},{ }^{* *}$, * indicate significant at $1 \%, 5 \%$ and $10 \%$ respectively.

not only control industry and provincial effects but also control enterprise size, financial leverage and business age, and the results also shows that the coefficient of RMB exchange rate is -1.1362 (columns 2) and -0.1351 (columns 4 ), and significantly negative at $1 \%$. This means that RMB devaluation of 1 yuan each, the export business innovation level fell $114 \% / 14 \%$. The results of the control variables show that the coefficients of Lev and Shrcr1 are significantly negative, which indicates that enterprises with high debt ratio and high equity concentration have reduced R \& D investment when RMB devaluation. Overall, the 
regression results of the control variables are basically the same as those of the previous studies. The conclusion of the main regression is consistent with the test result of double difference, which to a certain extent verifies the robustness of the conclusion.

\section{Further Test}

\subsection{Nature of Property Grouping}

Table 4 examines the nature of property rights for the impact of RMB exchange rate on business innovation. Among them, Soe is 1 for state-owned enterprises and 0 for private-owned enterprises. Empirical results show that the coefficient of RMB exchange rate is significantly negative in column (2) (4) (private enterprise group), indicating that the nature of property rights, especially private enterprises, further inhibits the innovation of enterprises when the RMB exchange rate depreciates. In the group of state-owned enterprises listed in column (1) and (3), although the coefficient of the RMB exchange rate (Rate) is negative, it is not significant. This reflects the devaluation of the RMB exchange rate more inhibit the innovation of private exporters. The results of the control variables are basically the same as those in the main regression.

\subsection{Scale Grouping}

Table 5 examines the enterprise size for the impact of RMB exchange rate on enterprise innovation. Size $=1$ for large-scale enterprise group, Size $=0$ for small-scale enterprise group. The empirical results show that the coefficient of the RMB exchange rate in column (2) and (4) is significantly negative at the level of $5 \%$, indicating that the scale of the enterprise, especially the small-scale enterprises, further inhibits the innovation of enterprises when the RMB exchange rate depreciates. In the large-scale enterprise group in column (1) and (3), although the coefficient of the RMB exchange rate is negative, it is not significant. This reflects the devaluation of the RMB exchange rate more restricting the innovation of small-scale export enterprises. The results of the control variables are basically the same as those in the main regression.

\subsection{Industry Competition Degree Grouping}

Table 6 examines the degree of competition in the industry for the impact of $\mathrm{RMB}$ exchange rate on business innovation. $\mathrm{Hhi}=0$ is the group with high degree of competition in the industry, and $\mathrm{Hhi}=1$ is the group with low degree of competition in the industry. Empirical results show that the coefficient of the RMB exchange rate is significantly negative in (2) and (4), which indicates that the enterprises in the industry competition degree, especially the high industry competition degree, more inhibit the innovation of the enterprises when the $\mathrm{RMB}$ exchange rate depreciates. In the group of enterprises with low degree of industrial competition in column (1), the coefficients of the RMB exchange rate are positive and not significant. In the group of enterprises with low level of 
Table 4. Ownership property group results.

\begin{tabular}{|c|c|c|c|c|}
\hline & (1) & (2) & (3) & (4) \\
\hline & \multicolumn{2}{|c|}{ Rd } & \multicolumn{2}{|c|}{ Rda } \\
\hline & Soe $=1$ & Soe $=0$ & Soe $=1$ & Soe $=0$ \\
\hline \multirow[t]{2}{*}{ Rate } & -0.8816 & $-1.2214^{* *}$ & -0.0636 & $-0.1693^{* * *}$ \\
\hline & $(-1.01)$ & $(-2.50)$ & $(-0.62)$ & $(-2.73)$ \\
\hline \multirow[t]{2}{*}{ Size } & $0.8435^{\star * *}$ & $0.9502^{* * *}$ & $-0.0601^{\star *}$ & $-0.0456^{\star *}$ \\
\hline & $(3.78)$ & $(6.56)$ & $(-2.24)$ & $(-2.47)$ \\
\hline \multirow[t]{2}{*}{ Age } & -0.0211 & -0.0081 & $-0.0115^{\star * *}$ & -0.0010 \\
\hline & $(-0.61)$ & $(-0.41)$ & $(-3.01)$ & $(-0.39)$ \\
\hline \multirow[t]{2}{*}{ Lev } & -0.9683 & $-4.5948^{\star * \star}$ & $-0.3365^{\star \star}$ & $-0.3613^{\star * *}$ \\
\hline & $(-0.79)$ & $(-5.89)$ & $(-2.49)$ & $(-4.03)$ \\
\hline \multirow[t]{2}{*}{$\mathrm{Fc}$} & $2.5296^{\star \star}$ & $-1.9656^{* * *}$ & 0.0389 & -0.0540 \\
\hline & $(2.37)$ & $(-3.18)$ & $(0.31)$ & $(-0.76)$ \\
\hline \multirow[t]{2}{*}{ Roe } & -2.0521 & $-1.7614^{*}$ & 0.0255 & -0.2229 \\
\hline & $(-1.58)$ & $(-1.72)$ & $(0.23)$ & $(-1.61)$ \\
\hline \multirow[t]{2}{*}{ Shrcr1 } & $-0.0333^{* * *}$ & $-0.0451^{* * *}$ & -0.0015 & $-0.0048^{* * *}$ \\
\hline & $(-3.10)$ & $(-6.68)$ & $(-1.33)$ & $(-5.60)$ \\
\hline \multirow[t]{2}{*}{ Cfo } & $-5.3395^{\star \star}$ & $-4.5833^{* * \star}$ & 0.2137 & 0.0897 \\
\hline & $(-2.37)$ & $(-3.39)$ & $(0.80)$ & $(0.52)$ \\
\hline \multirow[t]{2}{*}{ Employee } & 0.2657 & $0.2939^{\star *}$ & $0.0498^{*}$ & $0.0946^{* * *}$ \\
\hline & $(1.18)$ & $(2.14)$ & (1.94) & $(5.37)$ \\
\hline \multirow[t]{2}{*}{ Export } & -0.1360 & -0.0717 & 0.0142 & 0.0019 \\
\hline & $(-1.53)$ & $(-1.42)$ & $(1.41)$ & $(0.30)$ \\
\hline \multirow[t]{2}{*}{ Constant } & -7.2886 & -5.5594 & $1.5522^{* *}$ & $1.9649^{* * *}$ \\
\hline & $(-1.12)$ & $(-1.41)$ & $(2.00)$ & $(3.91)$ \\
\hline Industry & Yes & Yes & Yes & Yes \\
\hline Province & Yes & Yes & Yes & Yes \\
\hline Observations & 2748 & 5787 & 2749 & 5787 \\
\hline Adj. $R^{2}$ & 0.112 & 0.137 & 0.108 & 0.0939 \\
\hline
\end{tabular}

Note: The parentheses in the table are the $\mathrm{Z} / \mathrm{T}$ values corrected by the corporate dimension Cluster; ${ }^{* * *}$, $* *$, ${ }^{*}$ indicate significant at $1 \%, 5 \%$ and $10 \%$ respectively.

industrial competition in column (3), although the exchange rate of RMB Rate is negative, but not significant. This reflects the devaluation of the RMB exchange rate more inhibit the innovation of exporting enterprises faced with high degree of competition in the industry. The results of the control variables are basically the same as those in the main regression.

\section{Robustness Test}

\subsection{Considering the Impact of RMB Exchange Rate Lag}

According to the existing literatures, the RMB exchange rate, as a macroeconomic 
Table 5. Size grouping results.

\begin{tabular}{|c|c|c|c|c|}
\hline & (1) & (2) & (3) & (4) \\
\hline & \multicolumn{2}{|c|}{$\mathrm{Rd}$} & \multicolumn{2}{|c|}{ Rda } \\
\hline & Size $=1$ & Size $=0$ & Size $=1$ & Size $=0$ \\
\hline \multirow[t]{2}{*}{ Rate } & -0.7060 & $-1.3797^{\star *}$ & -0.0623 & $-0.1847^{\star *}$ \\
\hline & $(-1.10)$ & $(-2.44)$ & $(-0.84)$ & $(-2.42)$ \\
\hline \multirow[t]{2}{*}{ Size } & $0.7088^{* * *}$ & $1.0653^{\star * *}$ & $-0.0746^{\star * *}$ & -0.0300 \\
\hline & $(3.54)$ & $(4.76)$ & $(-3.33)$ & $(-0.96)$ \\
\hline \multirow[t]{2}{*}{ Age } & $0.0493^{*}$ & $-0.0601^{\star * *}$ & -0.0003 & $-0.0077^{\star *}$ \\
\hline & $(1.84)$ & $(-2.74)$ & $(-0.10)$ & $(-2.48)$ \\
\hline \multirow[t]{2}{*}{ Lev } & $-2.9287^{\star * *}$ & $-4.3192^{\star * *}$ & $-0.2275^{\star \star}$ & $-0.4576^{\star * *}$ \\
\hline & $(-3.04)$ & $(-4.80)$ & $(-2.18)$ & $(-4.29)$ \\
\hline \multirow[t]{2}{*}{$\mathrm{Fc}$} & 0.0235 & $-1.6861^{* *}$ & 0.0114 & -0.1071 \\
\hline & $(0.03)$ & $(-2.36)$ & $(0.13)$ & $(-1.24)$ \\
\hline \multirow[t]{2}{*}{ Roe } & -0.2268 & $-3.1346^{* * *}$ & $0.2768^{* *}$ & $-0.4830^{\star * *}$ \\
\hline & $(-0.18)$ & $(-2.91)$ & $(2.44)$ & $(-3.48)$ \\
\hline \multirow[t]{2}{*}{ Soe } & $0.9374^{* * *}$ & -0.3047 & $0.1143^{* * *}$ & 0.0174 \\
\hline & $(3.44)$ & $(-0.96)$ & (3.39) & $(0.40)$ \\
\hline \multirow[t]{2}{*}{ Shrcr1 } & $-0.0314^{\star * *}$ & $-0.0540^{* * *}$ & $-0.0027^{\star * *}$ & $-0.0053^{\star * *}$ \\
\hline & $(-3.92)$ & $(-6.81)$ & $(-3.02)$ & $(-4.99)$ \\
\hline \multirow[t]{2}{*}{ Cfo } & $-8.3065^{* * *}$ & -2.0640 & 0.0647 & 0.0950 \\
\hline & $(-4.48)$ & $(-1.40)$ & $(0.29)$ & $(0.50)$ \\
\hline \multirow[t]{2}{*}{ Employee } & $0.5332^{\star * *}$ & 0.0586 & $0.0962^{\star * *}$ & $0.0769^{* * *}$ \\
\hline & $(3.15)$ & $(0.35)$ & (5.14) & $(3.40)$ \\
\hline \multirow[t]{2}{*}{ Export } & $-0.2860^{\star * *}$ & 0.0363 & -0.0070 & 0.0065 \\
\hline & $(-4.18)$ & $(0.66)$ & $(-0.89)$ & $(0.93)$ \\
\hline \multirow[t]{2}{*}{ Constant } & -5.7564 & -6.2090 & $1.7836^{* * *}$ & $1.7958^{\star \star}$ \\
\hline & $(-1.09)$ & $(-1.11)$ & $(2.91)$ & $(2.38)$ \\
\hline Industry & Yes & Yes & Yes & Yes \\
\hline Province & Yes & Yes & Yes & Yes \\
\hline Observations & 4496 & 4039 & 4497 & 4039 \\
\hline Adj. $R^{2}$ & 0.130 & 0.107 & 0.116 & 0.0821 \\
\hline
\end{tabular}

Note: The parentheses in the table are the Z/T values corrected by the corporate dimension Cluster; ${ }^{* *}$, ${ }^{* *}$, * indicate significant at $1 \%, 5 \%$ and $10 \%$ respectively.

factor in the production and operation of enterprises, may have a lagged impact on the investment of enterprises. Therefore, this paper uses the lagged RMB exchange rate and innovation investment for robust regression, and the specific test results in Table 7. The test results show that: after considering the impact of the RMB exchange rate lag, the empirical test results did not change, consistent 
Table 6. Industry competitive group results.

\begin{tabular}{|c|c|c|c|c|}
\hline & (1) & (2) & (3) & (4) \\
\hline & \multicolumn{2}{|c|}{$\mathrm{Rd}$} & \multicolumn{2}{|c|}{ Rda } \\
\hline & Hhi $=1$ & Hhi $=0$ & Hhi $=1$ & Hhi $=0$ \\
\hline \multirow[t]{2}{*}{ Rate } & 0.1357 & $-1.2339^{* * *}$ & -0.0294 & $-0.1405^{\star *}$ \\
\hline & $(0.13)$ & $(-2.61)$ & $(-0.42)$ & $(-2.30)$ \\
\hline \multirow[t]{2}{*}{ Size } & 0.2232 & $1.1027^{\star * *}$ & -0.0273 & $-0.0530^{* * *}$ \\
\hline & $(1.07)$ & $(7.88)$ & $(-1.49)$ & $(-2.99)$ \\
\hline \multirow[t]{2}{*}{ Age } & 0.0111 & -0.0096 & $-0.0058^{*}$ & -0.0034 \\
\hline & $(0.29)$ & $(-0.51)$ & $(-1.83)$ & $(-1.39)$ \\
\hline \multirow[t]{2}{*}{ Lev } & -0.8705 & $-3.5271^{* * *}$ & -0.0941 & $-0.3890^{* * *}$ \\
\hline & $(-0.64)$ & $(-4.75)$ & $(-0.92)$ & $(-4.46)$ \\
\hline \multirow[t]{2}{*}{$\mathrm{Fc}$} & -0.6224 & -0.5110 & $-0.1768^{\star *}$ & -0.0233 \\
\hline & $(-0.52)$ & $(-0.85)$ & $(-2.07)$ & $(-0.33)$ \\
\hline \multirow[t]{2}{*}{ Roe } & -2.5389 & -1.0264 & -0.0147 & -0.0138 \\
\hline & $(-1.51)$ & $(-1.12)$ & $(-0.14)$ & $(-0.13)$ \\
\hline \multirow[t]{2}{*}{ Soe } & $-1.2460^{\star * *}$ & $0.7453^{* * *}$ & -0.0388 & $0.0879^{* * *}$ \\
\hline & $(-2.85)$ & $(3.22)$ & $(-1.15)$ & $(2.89)$ \\
\hline \multirow[t]{2}{*}{ Shrcr1 } & -0.0093 & $-0.0503^{\star * *}$ & $-0.0031^{* * *}$ & $-0.0044^{* * *}$ \\
\hline & $(-0.70)$ & $(-8.04)$ & $(-3.56)$ & $(-5.63)$ \\
\hline \multirow[t]{2}{*}{ Cfo } & -2.4267 & $-5.2706^{* * *}$ & -0.1106 & 0.0994 \\
\hline & $(-0.99)$ & $(-4.02)$ & $(-0.72)$ & $(0.58)$ \\
\hline \multirow[t]{2}{*}{ Employee } & -0.0279 & $0.3152^{\star *}$ & 0.0039 & $0.0993^{\star * *}$ \\
\hline & $(-0.14)$ & $(2.26)$ & $(0.27)$ & $(5.62)$ \\
\hline \multirow[t]{2}{*}{ Export } & 0.0956 & $-0.1500^{* * *}$ & 0.0002 & 0.0017 \\
\hline & $(1.07)$ & $(-3.03)$ & $(0.03)$ & $(0.28)$ \\
\hline \multirow[t]{2}{*}{ Constant } & -3.1754 & $-9.3618^{\star *}$ & $1.2247^{\star *}$ & $1.8358^{* * *}$ \\
\hline & $(-0.45)$ & $(-2.51)$ & $(2.17)$ & $(3.82)$ \\
\hline Industry & Yes & Yes & Yes & Yes \\
\hline Province & Yes & Yes & Yes & Yes \\
\hline Observations & 1242 & 7293 & 1243 & 7293 \\
\hline Adj. $R^{2}$ & 0.140 & 0.124 & 0.0637 & 0.0893 \\
\hline
\end{tabular}

Note: The parentheses in the table are the Z/T values corrected by the corporate dimension Cluster; ${ }^{* * *},{ }^{* *}$, * indicate significant at $1 \%, 5 \%$ and $10 \%$ respectively.

with the results of the main regression of this paper. Among them, (1) and (3) are listed as the result of ignoring the control variables. The coefficient of the RMB exchange rate is significantly negative at least at $5 \%$ level. (2) (4) are the result of considering the control variables, the RMB exchange rate (Rate) coefficients are also significantly negative at least at the $5 \%$ level. This is consistent 
Table 7. Consideration of exchange rate lag effect.

\begin{tabular}{|c|c|c|c|c|}
\hline & (1) & (2) & (3) & (4) \\
\hline & \multicolumn{2}{|c|}{$\mathrm{Rd}$} & \multicolumn{2}{|c|}{ Rda } \\
\hline \multirow[t]{2}{*}{ Rate } & $-1.7713^{* * *}$ & $-1.3577^{\star * *}$ & $-0.0892^{\star *}$ & $-0.1279^{\star *}$ \\
\hline & $(-5.31)$ & $(-3.26)$ & $(-2.16)$ & $(-2.49)$ \\
\hline \multirow[t]{2}{*}{ Size } & & $0.8348^{* * *}$ & & $-0.0578^{\star *}$ \\
\hline & & $(3.89)$ & & $(-2.19)$ \\
\hline \multirow[t]{2}{*}{ Age } & & -0.0155 & & -0.0040 \\
\hline & & $(-0.48)$ & & $(-0.99)$ \\
\hline \multirow[t]{2}{*}{ Lev } & & $-2.8687^{\star *}$ & & $-0.3026^{\star *}$ \\
\hline & & $(-2.50)$ & & $(-2.42)$ \\
\hline \multirow[t]{2}{*}{ Fc } & & -0.2980 & & -0.0032 \\
\hline & & $(-0.33)$ & & $(-0.03)$ \\
\hline \multirow[t]{2}{*}{ Roe } & & -1.1861 & & -0.0205 \\
\hline & & $(-1.11)$ & & $(-0.17)$ \\
\hline \multirow[t]{2}{*}{ Soe } & & 0.5395 & & 0.0775 \\
\hline & & $(1.32)$ & & $(1.45)$ \\
\hline \multirow[t]{2}{*}{ Shrcr1 } & & $-0.0456^{* * *}$ & & $-0.0042^{* * *}$ \\
\hline & & $(-4.19)$ & & $(-3.23)$ \\
\hline \multirow[t]{2}{*}{ Cfo } & & $-5.4343^{\star * *}$ & & 0.0508 \\
\hline & & $(-3.45)$ & & $(0.24)$ \\
\hline \multirow[t]{2}{*}{ Employee } & & 0.3170 & & $0.0839^{* * *}$ \\
\hline & & $(1.51)$ & & $(3.23)$ \\
\hline \multirow[t]{2}{*}{ Export } & & -0.1133 & & 0.0011 \\
\hline & & $(-1.48)$ & & $(0.12)$ \\
\hline \multirow[t]{2}{*}{ Constant } & $14.3834^{\star * *}$ & -3.4461 & $0.7678^{\star *}$ & $1.9158^{* * *}$ \\
\hline & (5.56) & $(-0.65)$ & $(2.57)$ & (3.04) \\
\hline Industry & Yes & Yes & Yes & Yes \\
\hline Province & Yes & Yes & Yes & Yes \\
\hline Observations & 8535 & 8535 & 8536 & 8536 \\
\hline Adj. $R^{2}$ & 0.0928 & 0.116 & 0.0751 & 0.0840 \\
\hline
\end{tabular}

Note: The parentheses in the table are the Z/T values corrected by the corporate dimension Cluster; ${ }^{* * *},{ }^{* *}$, * indicate significant at $1 \%, 5 \%$ and $10 \%$ respectively.

with the results in Table 4, indicating that after considering the impact of exchange rate lags, the conclusion of this paper remains robust.

\subsection{Replace Business Innovation Indicators}

To make another robust regression, this article uses the total investment in research and development indicators $\operatorname{Trd}\{\ln$ (enterprise research and development 
investment in the year +1$)\}$, Trda (enterprise R \& D investment/total assets * 100). It can be seen from Table 8 that in the four columns of regression equations, the exchange rate of $\mathrm{RMB}$ has a negative correlation with $\mathrm{R} \& \mathrm{D}$ investment, both of which are significant; that is, the more depreciated the RMB, the more it inhibits the enterprises' innovation investment. Specifically, column (1) and column (3) only control industry and provincial effects and the results show

Table 8. Results of replacing enterprise innovation index.

\begin{tabular}{|c|c|c|c|c|}
\hline \multirow[b]{3}{*}{ Rate } & (1) & (2) & (3) & (4) \\
\hline & \multicolumn{2}{|c|}{ Trd } & \multicolumn{2}{|c|}{ Trda } \\
\hline & $-3.4681^{\star * *}$ & $-3.9251^{* * *}$ & $-0.4177^{* * *}$ & $-0.4345^{\star * *}$ \\
\hline & $(-14.00)$ & $(-15.28)$ & $(-6.42)$ & $(-6.76)$ \\
\hline \multirow[t]{2}{*}{ Size } & & $0.7303^{\star * \star}$ & & $-0.4144^{\star \star \star x}$ \\
\hline & & $(4.59)$ & & $(-10.74)$ \\
\hline \multirow[t]{2}{*}{ Age } & & $0.0457^{\star \star}$ & & 0.0045 \\
\hline & & (2.19) & & $(0.77)$ \\
\hline \multirow[t]{2}{*}{ Lev } & & $-3.7789^{* * *}$ & & 0.3112 \\
\hline & & $(-4.45)$ & & (1.49) \\
\hline \multirow[t]{2}{*}{$\mathrm{Fc}$} & & $1.6471^{\star * *}$ & & $1.4360^{* * *}$ \\
\hline & & $(2.75)$ & & $(8.15)$ \\
\hline \multirow[t]{2}{*}{ Roe } & & $-4.5355^{* * *}$ & & $0.8602^{* * *}$ \\
\hline & & $(-4.87)$ & & $(3.74)$ \\
\hline \multirow[t]{2}{*}{ Soe } & & $-1.9350^{\star * *}$ & & $-0.1392^{*}$ \\
\hline & & $(-7.75)$ & & $(-1.95)$ \\
\hline \multirow[t]{2}{*}{ Shrcr1 } & & -0.0040 & & $-0.0049^{* *}$ \\
\hline & & $(-0.56)$ & & $(-2.44)$ \\
\hline \multirow[t]{2}{*}{ Cfo } & & $5.5388^{\star * *}$ & & $2.4886^{* * *}$ \\
\hline & & $(4.35)$ & & $(6.92)$ \\
\hline \multirow[t]{2}{*}{ Employee } & & $0.5776^{* * *}$ & & $0.3642^{* * *}$ \\
\hline & & $(3.72)$ & & $(9.42)$ \\
\hline \multirow[t]{2}{*}{ Export } & & -0.0267 & & $0.0406^{* * *}$ \\
\hline & & $(-0.53)$ & & $(2.76)$ \\
\hline \multirow[t]{2}{*}{ Constant } & $32.7529^{* * *}$ & $17.1975^{\star * \star}$ & $3.4802^{* * *}$ & $8.5899^{* * *}$ \\
\hline & (14.13) & $(5.29)$ & $(6.98)$ & (10.98) \\
\hline Industry & Yes & Yes & Yes & Yes \\
\hline Province & Yes & Yes & Yes & Yes \\
\hline Observations & 8536 & 8536 & 8536 & 8536 \\
\hline Adj. $R^{2}$ & 0.149 & 0.200 & 0.203 & 0.289 \\
\hline
\end{tabular}

Note: The parentheses in the table are the Z/T values corrected by the corporate dimension Cluster; ${ }^{* * *}{ }^{* *}$, * indicate significant at $1 \%, 5 \%$ and $10 \%$ respectively. 
that the coefficient of the RMB exchange rate is significantly negative at the level of $1 \%$. Column (2) and (4) not only control industries and provincial effect but also control firm size, financial leverage and business age. And the results also show that the coefficient of the RMB exchange rate is significantly negative at $1 \%$. By replacing the index of enterprise innovation, the conclusion of this paper is steady.

\section{Conclusions}

This paper uses Chinese A-share listed companies from 2011 to 2016 as a sample to examine the impact of RMB devaluation on enterprise innovation from the perspective of investment motivation. The study found that RMB devaluation significantly inhibited the innovation of export enterprises. From the conclusion of this article, although the RMB devaluation can enhance the market competitiveness of export products and enhance corporate profits, due to the profit-seeking nature and investment short-sightedness of enterprises, they will reduce $\mathrm{R} \& \mathrm{D}$ investment while increasing productive investment and expanding the scale of exports, and ultimately inhibit the business innovation. From this perspective, it is understood that the devaluation of the RMB has had a negative impact on the industrial upgrading and transformation of China's current stage of supply-side reform. Therefore, the research in this paper provides more reference for the government to formulate the macro-policy to promote the transformation of economic growth mode.

Of course, there are still some shortcomings in this article. Using Chinese listed companies to study the devaluation of RMB exchange rate and the impact of enterprise innovation, the conclusion of this study may not necessarily be extended to SMEs. Future research can use SMEs sample data to study the impact of RMB devaluation on the innovation of SMEs in China. In addition, due to the limitations of data acquisition, this paper does not study the relationship between exchange rate changes and the efficiency of enterprise innovation, and deepening the research in the future will be a direction.

\section{References}

[1] Pan, H.B. and Chen, S.L. (2017) The Kinship and Business Innovation of CEO or Chairman-Evidence from Family Listed Companies. Journal of Shanxi University of Finance and Economics, No. 1, 70-82.

[2] Song, J.B. and Wen, W. (2016) Does Director's Overseas Background Can Promote Business Innovation? China Soft Science, No. 11, 109-120.

[3] Chen, C. and Liu, T.Y. (2012) Founding Manager, Management Decentralization and R \& D Decision. Financial Research, No. 7, 196-206.

[4] Liu, S.Q., Lin, Z.J., Sun, F.C. and Chen, H.W. (2015) Financing Constraints and Agency Costs on Firm's R \& D Investment: Empirical Evidence Based on Chinese Listed Companies. Accounting Research, No. 11, 62-68 + 97.

[5] Nitani, M. and Riding, A. (2013) Growth, R \& D Intensity and Commercial Lender Relationships. Journal of Small Business \& Entrepreneurship, 26, 109-124. 
https://doi.org/10.1080/08276331.2013.771852

[6] Pan, Y., Pan, J.P. and Dai, Y.Y. (2015) Corporate Litigation Risk, Judicial Local Protectionism and Enterprise Innovation. Economic Research, 50, 131-145.

[7] Yang, D., Chen, H. and Liu, Q. (2017) Media Pressure and Business Innovation. Economic Research, 52, 125-139.

[8] Bernstein, S. (2015) Does Going Public Affect Innovation? Journal of Finance, 70, 1365-1403. https://doi.org/10.1111/jofi.12275

[9] Manso, G. (2011) Motivating Innovation. Journal of Finance, 66, 1823-1860. https://doi.org/10.1111/j.1540-6261.2011.01688.x

[10] Li, J., Xue, H. and Pan, Z. (2016) Manufacturing Enterprise Product Market Competition, Organizational Redundancy and Technological Innovation. China's Economic Problems, No. 2, 112-125.

[11] Jane, Z., Tan, L., Lv, D. and Fu, T. (2017) Market Competition, Creativity, Destructive and Technological Upgrading. China Industrial Economics, No. 5, 16-34.

[12] Zhang, J., Zhou, X. and Li, Y. (2011) Do Market Distortions of Factors Inhibit the Chinese Enterprises R \& D? Economic Research, 46, 78-91.

[13] Dai, K. and Liu, Y. (2013) Market-Oriented Process and Innovation Performance-An Empirical Analysis of China's High-Tech Industry. Equilibrium Economics and Technology Economy Research, 30, 37-54.

[14] Li, W. and Zheng, M. (2016) Substantive Innovation or Strategic Innovation?-The Impact of Macro-Industrial Policies on Micro-Enterprise Innovation. Economic Research, 51, 60-73.

[15] Qin, X.Z., Yin, Z., Zhou, J. and Kong, X. (2012) National Science and Technology Program and SME Innovation: An Analysis Based on Matching Model. Management World, No. 4, 70-81.

[16] Wang, W. and Rong, Z. (2014) Research on the Influence of Rising Housing Price on the Innovation of Industrial Enterprises. Economics Quarterly, 13, 465-490.

[17] Wang, H., Li, M. and Tang, T. (2016) Entrepreneurial Cross-Industry Arbitrage and Its Driving Factors for Innovation. China's Industrial Economy, No. 11, 73-89.

[18] Gao, J., Xu, M. and Kong, D. (2015) Regional Legal Protection and Business Innovation. Scientific Research Management, 36, 92-102.

[19] Ni, X.R. and Zhu, Y. (2016) Labor Protection, Labor Intensity and Enterprise Innovation-Evidence from the Implementation of the Labor Contract Law 2008. Management World, No. 7, 154-167.

[20] Wang, H. and Lv, T. (2016) Judicial Protection of Intellectual Property and Enterprise Innovation-A Quasi-Natural Experiment Based on the "Three Combinations" of Cases of Intellectual Property in Guangdong Province. Management World, No. 10, 118-133.

[21] Xu, J., Tong, J., Mao, Q., et al. (2015) RMB Exchange Rate, Product Quality and Firms' Export Activity: An Empirical Analysis Based on Chinese Manufacturing Enterprises. Journal of Financial Research, No. 3, 1-17.

[22] Harris, R.G. (2001) Is There a Case for Exchange Rate Induced Productivity Changes? Canadian Institute for Advanced Research Working Paper, No. 164.

[23] Zhang, H. and Tang, H. (2012) RMB Appreciation, Corporate Behavior and Export Trade-An Empirical Study Based on Large Sample Enterprise Data: 2005-2009. Management World, No. 12, 23-34 + $45+187$.

[24] Li, H., Ma, H., Xiong, Y. and Xu, Y. (2011) Impact of RMB Exchange Rate on Im- 
port and Export Trade of Enterprises-An Empirical Study of Chinese Enterprises. Financial Research, No. 2, 1-16.

[25] Liang, Z. and Yu, M.J. (2014) RMB Appreciation and the Profitability of Chinese Export Enterprises-An Empirical Analysis Based on Panel Data. Financial Research, No. 7, 1-15.

[26] Wu, G. (2017) Impact of Changes in Corporate Effective Exchange Rate on Corporate Profits. World Economy, 40, 49-72.

[27] Tong, J., Xu, J. and Mao, Q. (2016) RMB Exchange Rate, Enterprise Export Margins and Export Dynamics. World Economy Research, No. 3, 70-85 + 135.

[28] Li, H., Ma, H. and Xu, Y. (2015) How Do Exchange Rate Movements Affect Chinese Exports?-A Firm-Level Investigation. Journal of International Economics, 97, 148-161. https://doi.org/10.1016/j.jinteco.2015.04.006

[29] Mao, R., Gao, L. and Zheng, J. (2017) Study on the Impact of RMB Real Exchange Rate Change on Export Conversion. Management World, No. 3, 9-28 + 187.

[30] Campa, J.M. and Goldberg, L.S. (1995) Investment in Manufacturing, Exchange Rates and External Exposure. Journal of International Economics, 38, 297-320. https://doi.org/10.1016/0022-1996(94)01348-V

[31] Liu, Q.R. and Huang, J.Z. (2017) RMB Exchange Rate Changes and Export Enterprise Research and Development. Financial Research, No. 8, 19-34.

[32] Yu, J.W. (2016) Changes in RMB Exchange Rate, Market Competition and Enterprise Innovation. World Economic Research, No. 4, 51-65 + 135.

[33] Ekholm, K., Moxnes, A. and Ulltveitmoe, K.H. (2012) Manufacturing Restructuring and the Role of Real Exchange Rate Shocks. Journal of International Economics, 86, 101-117. https://doi.org/10.1016/j.jinteco.2011.08.008

[34] Tang, Y. (2011) Does Productivity Respond to Exchange Rate Appreciations? A Theoretical and Empirical Investigation. Working Papers.

[35] Wu, G. and Jiang, G. (2015) RMB Exchange Rate Changes and Manufacturing Investment-Evidence from the Enterprise Level. Financial Research, No. 11, 1-14.

[36] Schumpeter, J. (1942) Capitalism, Socialism and Democracy. Harper, New York.

[37] Li, D., Long, Y. and Yang, J. (2015) Anti-Corruption and Business Innovation: An Explanation Based on Political Connections. China Industrial Economics, No. 7, 146-160.

[38] Yu, Y. and Zhang, S. (2017) Urban Housing Prices, Purchase Policy and Technological Innovation. China Industrial Economics, No. 6, 98-116.

[39] Alvarez, R., Doyle, M. and López, R.A. (2009) Exchange Rate Volatility and Export Margins. Working Papers Central Bank of Chile.

[40] Clark, P., Tamirisa, N., Wei, S.-J., Sadikov, A. and Zeng, L. (2004) Exchange Rate Volatility and Trade Flows: Some New Evidence. International Monetary Fund, Working Paper, 1-131.

[41] Mckenzie, M.D. (1999) The Impact of Exchange Rate Volatility on International Trade Flows. Journal of Economic Surveys, 13, 71-106. https://doi.org/10.1111/1467-6419.00075

[42] Tan, X., Wang, Y. and Lu, B. (2016) Exchange Rate Fluctuations, Financial Market and Export. Financial Research, No. 3, 15-30.

[43] Lu, Z. (2015) Research on the Impact of RMB Exchange Rate Fluctuations on the Operating Conditions of Export Enterprises. Microeconomic Research, No. 3, 38-49. 
[44] Cai, X. and Ru, Y. (2016) Does Local Government Infrastructure Investment will Curb Corporate Technological Innovation?-Based on the Empirical Research of Chinese Manufacturing Enterprises Data. Management World, No. 11, 32-52.

[45] Luo, C. and Ji, X. (2015) Financing Restrictions on Export and R \& D of Enterprises: Does "Fish" and "Bear's Paw" Not Available. Financial Research, No. 9, 140-158. 